\title{
Effect of Mind Mapping Instructional Strategy on Students' Retention in Physics in Senior Secondary Schools
}

Abdulrasaq Oladimeji Akanbi

Ph.D., Department of Science Education, University of Ilorin, Ilorin, Nigeria, akanbi.ao@unilorin.edu.ng

Yahaya Wasiu Olayinka

Department of Science Education, University of Ilorin, Ilorin, Nigeria, yahayawasiu361@ gmail.com

Esther Ore Omosewo

Prof., Department of Science Education, University of Ilorin, Ilorin, Nigeria, oresewo2k@gmail.com

Ridwan Enuwa Mohammed

Ph.D., Department of Science Education, University of Ilorin, Ilorin, Nigeria, mohammed.re@unilorin.edu.ng

This study examined the effect of mind mapping instructional strategy on students' retention in physics in senior secondary schools. The research is a quasi-experimental design of the pre-test, post-test, non-equivalent and non-randomized $2 \times 2 \times 3$ factorial design. 64 students were sampled for this study out of which 28 formed the experimental group (mind mapping instructional strategy) while 36 of the respondents constituted the control group (conventional method). The pre-test and post-test contained 20 multiple-choice questions with four options one of which was the key factor while others were distractors. Multiple-choice questions were validated by three university professors. A retention test was also conducted after 2 weeks of the whole exercise. Data collected were analysed using the mean and standard deviation to answer the research question while hypotheses were tested using Analysis of Covariance (ANCOVA) and independent t-test at 0.05 significant level. Findings revealed among others that there was a significant effect of the mind mapping instructional strategy in physics in senior secondary schools It was therefore, recommended among others that mind mapping instructional strategy should be used to teach physics concept at the senior secondary school level of education for a better performance because it improves students' performances in physics.

Keywords: physics teaching, mind mapping instructional strategy, retention, senior secondary school, physics

\section{INTRODUCTION}

Physics is one of the basic science subjects offered at the senior secondary school in Nigeria. Physics is an important subject in the secondary school curriculum because it helps the learners to apply the principles acquired through knowledge and skills to construct appropriate scientific devices from available resources (Feinstein, 2011; Kiboss, 2011). In addition, it prepares learners for scientific and technological vocations and this plays a major role in technological, socio-economic and industrial development in many countries of the world. (Mirko, Dusanka \& Mirjana, 2012). Physics is a key discipline in producing qualified engineers, scientists, teachers and researchers among others.

Citation: Akanbi, A. O., Olayinka, Y. W., Omosewo, E. O., \& Mohammed, R. E. (2021). Effect of Mind Mapping Instructional Strategy on Students' Retention in Physics in Senior Secondary Schools. Anatolian Journal of Education, 6(1), 145-156. https://doi.org/10.29333/aje.2021.6112a 
Despite the importance of Physics as a key subject for the technological development of a nation, the students' performance is still below expectations (Ballah \& Ugwumba 2015). A number of reasons have been identified by researchers (Harry, 2011, King'aru, 2014, Ogunleye, 2009, Ogunleye, \& Babajide, 2011) as factors that are contributing to the poor and fluctuating performance in Physics. Some of the reasons adduced for the poor performance in physics include students' poor attitude towards physics, lack of motivation, poorly resourced teaching and learning environment, poor mathematical ability and poor teaching method. Furthermore, poor and fluctuating academic achievements in Physics could be attributed to the teacher's strategy which was considered as a critical factor (Oladejo, Olosunde, Ojebisi, \& Isola, 2011).

Erinosho, (2013) however made us realize that the teaching method employed by teachers' reflects on students' understanding of the subject and it is the important for teachers to understand and interpret the objectives of Physics for efficient, effective teaching and learning. It is therefore, necessary to use appropriate methods which involve students' active participation in teaching and learning. Teaching needs to be participatory, where all the domains of learning are engaged in learning, hence there is the need to introduce, adopt and adapt the recently used instructional strategy that are capable of sustaining not only the interest of the learners, but also helping them to understand the concepts (Adesoji \& Ibraheem, 2009).

There are many instructional strategies in the teaching process such as visual metaphor, conceptual maps, conceptual diagram, semantic networks, mind maps, and so on (Eppler, 2006; Parikh, 2015). Buzan and Buzan (2010) stated that the mind map is a powerful graphic organizer of ideas which provides a universal key to unlocking the potentials of the individual brain. Mind mapping is a highly effective way of getting information in and out of your brain. Mind mapping is also a creative and logical means of note-taking and note-making that literally "maps out" your ideas. It harnesses the full range of cortical skills, words, images number, logics, rhythm, colour and spatial awareness in a single uniquely powerful manner.

The mind mapping instructional strategy is an example of a non-linear approach to learning that encourages the learner to think radically and to use only key words and images that are non-linearly linked together for new and prior knowledge (Dhindsa \& Anderson, 2011). In the mind mapping, only essential words, clauses and phrases are used. This strategy is easy for the novice learner to apply and it also encourages self-expression and exploration of a concept by the student. There are no limits to associations and connections of the concept. Mind mapping allows the student to build upon existing knowledge when new information is presented that enables meaningful learning to take place (Buzan \& Buzan, 1996; Davies 2011; Spencer, Anderson, \& Ellis, 2013). All mind mapping have some things in common. They have a natural organizational structure that radiates from the centre and uses lines, symbols, words, colour and images according to simple, brain-friendly concepts. Mind mapping converts a long list of monotonous information into a colourful, memorable and highly organized diagram that works in line with your brain's natural way of doing things.

\section{Statement of Problem}

The aim of teaching at any level of education is to bring about the required change in the learner according to certain objectives (Tebabal \& Kahssay, 2011). In order to achieve this feat it is thus necessary that teachers apply the appropriate teaching methods and strategies that best suit the students in terms of their entry behavior so that the stated specific objectives can be achieved. Studies have shown that the poor performances of most students are usually linked to the types or modes of instruction employed by teachers to impart knowledge to the students, (Odunola, 2011). Therefore, this study investigated the effects of mind mapping instructional strategy on students' retention in senior secondary school physics in Ilorin. 


\section{Purpose of the Study}

The purpose of this study was to find out the effect of mind mapping instructional strategy on students' retention in senior secondary school physics in Ilorin. Specifically, the study aimed to find out the underlisted:

1. the performance of senior secondary school students in physics;

2. the effect of mind mapping instructional strategy on senior secondary school students in physics;

3. the interaction effect of mind mapping instructional strategy and gender on students' performance in physics .

4. the difference between the mean retention score of students that were taught physics using mind mapping instructional strategy and those taught without it.

5. the difference that exists in the mean retention score of male and female students taught physics using the mind mapping instructional strategy

\section{Research Questions}

The following research questions were raised and answered at $p<0.05$ level of significance:

1. What is the performance of senior secondary school students in physics?

2. Is there any effect of the mind mapping instructional strategy on senior secondary school students in physics?

3. Is there any interaction effect of the mind mapping instructional strategy and gender on students' performances in physics?

4. Is there any effect between the mean retention score of students that were taught physics using the mind mapping instructional strategy and those that were taught without it.

5. the existing difference between the mean retention score of male and female students that were taught physics using the mind mapping instructional strategy and those that were taught without it.

\section{Research Hypotheses}

The following hypotheses were formulated and tested at 0.05 levels of significance:

$\mathbf{H}_{01}$ : There is no significant effect of the mind mapping instructional strategy on senior secondary school students in physics

$\mathbf{H}_{02}$ : There is no significant interaction effect of the mind mapping instructional strategy and gender on students' performances in physics.

$\mathbf{H}_{\mathbf{0 3}}$ : There is no significant effect between the mean retention score of students who were taught physics using the mind mapping instructional strategy and those that were taught without it.

$\mathbf{H}_{04}$ : There is no significant effect between the mean retention score of male and female students that were taught physics using mind mapping instructional strategy.

\section{METHOD}

The research is a quasi-experimental design of the pre-test, post-test, non-equivalent and nonrandomized $2 \times 2 \times 3$ factorial design. The population of the study was all the senior secondary 
schools in Ilorin-East Local Government Area. The target population was the senior school two (SSS II) students that were offering physics in Ilorin-East Local Government Area. Two co-educational senior secondary schools were selected out of 36 senior secondary schools through the random sampling technique. Intact classes consisting of senior secondary II (SSII) students offering physics from two co-educational schools were purposively selected for this study in order to give every student the opportunity to participate in the study and not to disrupt class activities. The simple random sampling technique was used to divide the schools into experimental and control groups. This is because no specific requirement was needed to divide each school.

The experimental group (28 students) was exposed to the mind mapping instructional strategy by the research assistant that was specially trained by the researchers for the purpose. The research assistant was also equipped with an appropriate lesson plan. The research assistant took an active part in preparing the material with the help of the researchers and did all the necessary preparation in order to use the teaching method. The preparation was carried out within one week. The control group (36 students) was also taught by a school physics teacher using the conventional method of teaching with an appropriate lesson plan prepared by the researchers. The research was conducted in two secondary schools during the period allocated to physics on the class timetable. The mind mapping instructional strategy was used to teach simple harmonic motion during the lesson. All students were volunteers to participate in the study. Informed consent was obtained from all the participating students in the study. The pre-test and post-test contained 20 multiple-choice questions on Simple Harmonic Motion Retention Achievement Test (SHMRAT) with four options one of which was the key factor while the others were just distracters. Multiple-choice questions were validated by three university professors who were specialists in such area of physics. A pre-test was conducted for all the groups to determine their knowledge about the topic before the exercise started. The teaching was done for 4 weeks after which the post-test was administered to the students in all the groups. A retention test was also conducted after 2 weeks of the whole exercise. Data collected were analysed using the mean and standard deviation to answer the research question while hypotheses were tested using Analysis of Covariance (ANCOVA) and independent t-test at 0.05 significant level.

\section{FINDINGS}

Out of $64(100 \%)$ students sampled for this study $28(20.0 \%)$ of the respondents formed the experimental group (mind mapping instructional strategy) in which 15(23.5\%) were males and 13 (20.3\%) were females; $36(56.2 \%)$ of the remaining respondents constituted the control group (conventional method) out of which 16 (25.0\%) were males and 20 (31.2\%) were females.

Research Question One: What is the performance of senior secondary school students in physics?

As revealed in Table 1, the performances of students (both the experimental and control groups) in the post-test was higher than their performances in the pre-test. In the post test the performance (18.48) of students taught physics using the mind mapping instructional strategy was higher when compared to those exposed to the conventional method with the mean score (11.73) which was fair. Also students taught physics with mind mapping instructional strategy had the mean gain score 9.58 while students that were taught using conventional method had the mean gains score 3.64. 
Table 1

Descriptive statistics of students' performance in physics (before and after the treatment)

\begin{tabular}{lllllll}
\hline Groups & & Mean & S.D. & Min & Max & $\begin{array}{l}\text { Mean Gain } \\
\text { Scores }\end{array}$ \\
\hline Experimental & Pre-test & 8.90 & 4.41 & 4.00 & 14.00 & 9.58 \\
(Mind Mapping Instructional Strategy) & Post-test & 18.48 & 6.99 & 12.00 & 20.00 & \\
\hline Control & Pre-test & 8.09 & 3.79 & 5.00 & 12.00 & 3.64 \\
(Conventional Method) & Post-test & 11.73 & 4.56 & 7.00 & 16.00 & \\
\hline
\end{tabular}

\section{Hypotheses Testing}

$\mathbf{H o}_{1}$ : There is no significant effect of mind mapping instructional strategy on senior secondary school students in physics

The result in Table 2 reveals that the $F$-value of 332.457 is obtained with a p-value of 0.000 computed at 0.05 alpha level. Since p-value (0.000) is less than alpha level $(0.05)$, the null hypothesis one is rejected and thus, there was a statistically significant effect of the mind mapping instructional strategy on senior secondary school students in physics $\left(F_{(1,61)}=332.457, \mathrm{p}<0.05\right)$.

Table 2

Analysis of covariance results of the mind mapping instructional strategy on senior secondary school students' performance

\begin{tabular}{llllll}
\hline Source & Type III Sum of Squares & df & Mean Square & $F$ & Sig. \\
\hline Corrected Model & $756.689^{\mathrm{a}}$ & 2 & 378.344 & 168.384 & .000 \\
\hline Intercept & 1068.699 & 1 & 1068.699 & 475.631 & .000 \\
\hline Pre-test & 5.796 & 1 & 5.796 & 2.579 & .113 \\
\hline Mind mapping & 747.000 & 1 & 747.000 & 332.457 & .000 \\
\hline Error & 137.061 & 61 & 2.247 & & \\
\hline Total & 14234.000 & 64 & & & \\
\hline Corrected Total & 893.750 & 63 & & & \\
\hline a. R Squared $=.847$ (Adjusted R Squared $=.842)$ & & & & \\
\hline
\end{tabular}

The Multiple Comparison Analysis is depicted in Table 3 to show where the difference lies (i.e. the effect of the treatment on students' performance in physics). As shown in Table 3, students in the experimental group that were taught using the mind mapping instructional strategy had a higher adjusted mean score of 18.48 than those in the control group that were exposed to conventional method with an adjusted mean score of 11.73. Thus, the effect of the mind mapping instructional strategy on students' performance in physics is shown by the mean score difference 6.75 . 
Table 3

Pairwise comparisons analysis showing the effect of the treatment on students' performance in physics

\begin{tabular}{|c|c|c|c|c|c|c|}
\hline \multirow[b]{2}{*}{ Treatment } & \multirow[b]{2}{*}{ Mean } & \multirow[b]{2}{*}{$\begin{array}{l}\text { Mean Difference } \\
(\mathrm{I}-\mathrm{J})\end{array}$} & \multirow[b]{2}{*}{$\begin{array}{l}\text { Std. } \\
\text { Error }\end{array}$} & \multirow[b]{2}{*}{ Sig. ${ }^{\text {b }}$} & $\begin{array}{l}95 \% \\
\text { Interva }\end{array}$ & $\begin{array}{l}\text { Confidence } \\
\text { ference }^{b}\end{array}$ \\
\hline & & & & & $\begin{array}{l}\text { Lower } \\
\text { Bound }\end{array}$ & $\begin{array}{l}\text { Upper } \\
\text { Bound }\end{array}$ \\
\hline Experimental (I) & $18.48^{\mathrm{a}}$ & $6.75^{*}$ & .357 & 0.000 & 2.331 & 3.742 \\
\hline Control $(\mathrm{J})$ & $11.73^{\mathrm{a}}$ & $-6.75^{*}$ & .357 & 0.000 & -3.742 & -2.331 \\
\hline
\end{tabular}

Grand Mean $=15.105$

* the mean difference is significant at 0.05 level

b. Adjustment for Multiple Comparisons: Bonferroni

$\mathbf{H o}_{2}$ : There is no significant interaction effect of the mind mapping instructional strategy and gender on students' performance in Physics.

The result in Table 4 reveals that the $F$-value of 0.453 is obtained with a p-value of 0.507 computed at 0.05 alpha level. Since p-value (0.507) is greater than alpha level $(0.05)$, the null hypothesis two is not rejected and thus, there was no statistically significant interaction effect of the mind mapping instructional strategy and gender on students' performances in Physics $\left(F_{(1,25)}=0.453, \mathrm{p}>0.05\right)$.

Table 4

Analysis of covariance results showing the interaction effect of the mind mapping instructional strategy and gender on students' performance in physics

\begin{tabular}{llllll}
\hline Source & Type III Sum of Squares & df & Mean Square & $F$ & Sig. \\
\hline Corrected Model & $3.540^{\mathrm{a}}$ & 2 & 1.770 & .842 & .443 \\
\hline Intercept & 652.968 & 1 & 652.968 & 310.539 & .000 \\
\hline Pre-test & 2.858 & 1 & 2.858 & 1.359 & .255 \\
\hline Gender & .951 & 1 & .951 & .453 & .507 \\
\hline Error & 52.567 & 25 & 2.103 & & \\
\hline Total & 9455.000 & 28 & & & \\
\hline Corrected Total & 56.107 & 27 & & & \\
\hline a. R Squared $=.063$ (Adjusted R Squared $=-.012)$ & & & & \\
\hline
\end{tabular}

Ho $:$ There is no significant effect between the mean retention score of students who were taught physics using the mind mapping instructional strategy and those that were taught without it.

Table 5 shows that the t-value 1.714 is obtained with a p-value of 0.022 computed at 0.05 alpha level. Since the p-value of 0.022 is less than 0.05 level of significance, the null hypothesis three is not retained. Therefore, there was a statistically significant effect in the mean retention score of students who were taught physics using the mind mapping instructional strategy and those that were taught without it $\left(\mathrm{t}_{\{62\}}=1.714, \mathrm{p}<0.05\right)$. The retention ability of experimental group was found greater than that of the control group. The mind mapping instructional strategy might have enhanced the retention ability of the students in physics. 
Table 5

T-test statistics showing the difference in the mean retention score of students who were taught physics using the mind mapping instructional strategy and those that were taught without it

\begin{tabular}{llllllll}
\hline Groups & No & Mean & S. D. & df & t-value & Sig & Remark \\
\hline Experimental & 28 & 16.821 & 3.409 & & & & \\
\hline & & & & 62 & 1.714 & 0.022 & Rejected \\
\hline Control & 36 & 13.975 & 3.454 & & & & \\
\hline *significance at $\mathrm{p}<0.05$ & & & & &
\end{tabular}

*significance at $\mathrm{p}<0.05$

$\mathbf{H}_{\mathbf{0 4}}$ : There is no significant effect between the mean retention score of male and female students that were taught physics the using the mind mapping instructional strategy.

Table 6 shows that the t-value 1.426 is obtained with a p-value of 0.320 computed at 0.05 alpha level. Since the p-value of 0.320 is greater than 0.05 level of significance, the null hypothesis four is retained. Therefore, there is no statistically significant effect in the mean retention score of male and female students that were taught physics using the mind mapping instructional strategy $\left(\mathrm{t}_{\{62\}}=1.426\right.$, $\mathrm{p}>0.05)$.

Table 6

T-test statistics showing the effect in the mean retention score of male and female students that were taught physics using the mind mapping instructional strategy

\begin{tabular}{llllllll}
\hline Gender & No & Mean & S. D. & df & t-value & Sig & Remark \\
\hline Male & 15 & 16.341 & 2.713 & & & & Not \\
\hline Female & 13 & 15.839 & 3.144 & & & & \\
\hline
\end{tabular}

*significance at $\mathrm{p}<0.05$

\section{DISCUSSION}

The result obtained showed that the performance (18.48) of students taught Physics using the mind mapping instructional strategy was higher when compared to those exposed to the conventional method with the mean score (11.73) which was fair. This may be due to the treatment students were exposed to during teaching. This result is in line with Adesoji and Ibraheem (2009) whose findings showed that students exposed to the mind mapping instructional strategy performed well than students with the conventional learning strategy in Mathematics. This was further supported by Çömek, Akinoğlu, Elmaci, and Gündoğdu (2016) who asserted that one of the techniques that can be used and applied by the teacher is the mind mapping instructional strategy to improve the learning outcome of students in any subject.

Findings revealed that there is a statistically significant effect of the mind mapping instructional strategy on senior secondary school students in physics. The students taught Physics with the mind mapping instructional strategy performed better than those taught by the conventional method. This may be because the mind map arose their interest in learning, increased their creative thinking and they were able to express themselves when using the mind mapping. The obtained result is in accordance with those of Adodo (2013), Jibril, Abdullahi, Zayum and Abdullahi (2012), Oluwatosin and Bello (2014), and Onyishi (2009) in their separate studies showed that the mind-mapping strategy helped to improve students' performances in sciences. Similar result was obtained in the research carried out by Comek, Akinoğlu, Elmaci, and Gundoğdu, (2016) in Turkey which showed that with the use of the mind mapping as improves students' academic achievement in science class. Besides, researchers in Korea had shown that the use of mind mapping in science teaching improved junior high school students' creative thinking skills (Yoon \& Kang, 2015). Researchers (Gagić, Skuban, Radulović, Stojanović, \& Gajić, 2019) in the Republic of Serbia have also provide beyond doubt the educational 
efficiency of teaching with the use of mind mapping which was found to be higher or greater than the efficiency of conventional teaching approach. Besides that the students' involvement in the experimental group was also found to be higher than the one in the control group.

Results have shown that there is no statistically significant interaction effect of the mind mapping instructional strategy and gender on students' performances in physics. This implies that male and female students exposed to the same treatment will not differ significantly in their performance scores in physics. This suggests that sex is not a barrier to performance when mind mapping is used. This is supported by the finding of Adodo (2004) that both sexes were not different in their studies when equally encouraged to use their intellectual gifts fully and that gender did not affect students learning of science and their performance. The finding also agrees with that of Alao and Abubakar (2011) that there is no significant difference between male and female students' performance in physics. Amedu (2015) revealed that gender has no influence on the students' academic performance in senior secondary schools. Udousoro (2011) found that gender does not have any significant effect on academic performance of students. However the result is at variance with Aina and Akintunde (2013) whose submission was that male students performed better than the female students in physics. Brown and Brown (2019) reported that gender influenced performance in the favour of females.

It was also reported that there was a significant difference between the mean retention score of students that were taught physics with the use of the mind mapping instructional strategy and those that were taught without it. The result may be due to the facts that the use of the mind mapping instructional strategy gives room for creativity. This implies that the treatment used improved students retention in physics. The study supported the findings of Akinwumi and Bello (2015), Ali (2013), Obunwo (2014), and Okeke (2011) that there was a significant difference in favour of the experimental group over the control group regarding the academic achievement, the scores of retention of learning, and the perception of inquiry-learning skill scores, both on cognitive and affective levels. However, the finding disagrees with the study of Oluwatosin and Bello (2015) that no significant effect of treatment was found in the retention ability of students who were taught with mastery learning approach and Mind Mapping Approach.

The findings also revealed gender as having no significant influence on the mean retention score of students that were taught physics with the use of mind mapping instructional strategy. The result of this finding disagrees however with the finding of Okeke (2012) that gender had a significant influence on the mean retention score of students taught with the use of mind mapping instructional strategy. The finding also disagrees with Anaekwe (1997) that reported a significant effect of students interaction patterns on students' achievement in favour of the female and a insignificant effect of retention in favour of the males. But the present study agrees with findings of John and Benjamin (2015) that male and female students taught algebra using problem-based learning did not significantly differ in achievement and retention scores, thereby revealing that male and female students are capable of competing and collaborating in mathematics. The result of this finding also agrees with Ezeudu (2013) that there was a significant difference in the overall achievement and retention between students exposed to concept mapping and students exposed to conventional methods. Gender was consistently insignificant to achievement and retention.

\section{CONCLUSION}

This study has provided empirical data on the effectiveness of the mind mapping instructional strategy in enhancing students' academic performances in physics. In this regard, this study concluded that the use of the mind mapping instructional strategy in the teaching of Physics at the secondary school level addressed the students' poor and fluctuating performances. The study also concluded that gender does not have any effects on the performances of students taught physics using the mind mapping instructional strategy. The study also concluded that students taught physics using the mind mapping 
instructional strategy retained physics concept more than those taught without it, and that gender does not influence students' retention in physics.

\section{SUGGESTIONS}

The following are therefore suggested based on the study:

1. The mind mapping instructional strategy should be used to teach physics concept at the senior secondary school level of education for a better performance because it improves students' performances in physics.

2. The mind mapping instructional strategy should be used to teach male and female students at senior secondary schools because the treatment improves the students' performances in physics.

3. The mind mapping instructional strategy should be used to teach students with a low retention ability because the treatment enhances students' performances in physics.

4. Male and Female students with a low retention capacity should be taught with the mind mapping instructional strategy. This is because it has improved students' performances.

\section{REFERENCES}

Adesoji, F. A., \& Ibraheem, T. L. (2009). Effects of students' teams-performance divisions strategy and mathematics knowledge on learning outcome in chemical kinematics. Journal of International Social Research, 2(6), 15-25

Adodo S.O. (2004), Influence of Gender and Environment on student's performance in Integrated Science in Secondary School Educational Thought. Research. Journal of the Faculty of Education A.A.U, Akungba Akoko 4(1), 70-77

Adodo, S. O. (2013). Effect of mind-mapping as a self-regulated learning strategy on students' achievement in basic science and technology. Mediterranean Journal of Social Sciences, 4(6), 163172. doi:10.5901/mjss.2013.v4n6p163.

Adunola, O. (2011). The importance of teachers' teaching methods on the academic performance of primary school pupils in Ijebu-ode local government area of Ogun state. Ego Booster Books: IjebuOde

Aina, J. K., \& Akintunde, Z. T. (2013). Analysis of gender performance in Physics in colleges of education, Nigeria. Journal of Education and Practice, 4(6), 1-5.

Akinwumi, M. O., \& Bello, T. O. (2015) Relative Effectiveness of Learning-cycle model and inquiryteaching approaches in improving Students' learning outcomes in Physics. Journal of Education and Human Development, 4(3) 169-180

Alao, A. A., \& Abubakar, R. B. (2011). Gender and academic performance of college Physics students: a case study of department of Physics/Computer science education, federal college of education, (technical), Omoku. Journal of Research in Education and Society, 1(1), 129-137.

Ali, G. (2013). The effect of mind-mapping applications on upper primary students 'success and inquiry learning skills in science and environment education [J]. International Research in Geographical and Environmental Education.

Amedu, O. I. (2015). The effect of gender on the achievement of students in biology using the jigsaw method. Journal of Education and Practice 6 (17), 176 - 179 www.iiste.org

Anaekwe, M. C (I997\} Effect of student's interaction patterns on students' cognitive Achievement, Retention and Interest in Chemistry. Unpublished Ph.D. Thesis, University of Nigeria, Nsukka 
Ballah, A. G., \& Ugwumba, A. O. (2015). Attitudes and academic performance of senior secondary school students in Physics in Nigeria. Paper presented at the proceedings of SOCOINTER15 $-2^{\text {nd }}$ International Conference on Education, Social Sciences and Humanities (pp. 499 - 508), Istanbul, Turkey.

Buzan, T. (2010). How to mind map. [video file]. Retrived from http://www.youtube.com/watch?v=4wZ5wV5dPZc

Buzan, T., \& Buzan, B. (1996). The mind map book: How to use radiant thinking to maximize your brain's untapped potential. New York: Dutton Adult.

Buzan, T., \& Buzan, B. (2010). The mind map book:unlock your creativity, boost your memory, change your life. Harlow, UK: Pearson

Brown, T., \& Brown, J. T. (2019). Gender difference in fieldtrip and video technology methods of teaching social studies in junior secondary schools. International Journal of Interdisciplinary Research Methods, 6(3), 1-9

Çömek, A., Akinoğlu, O., Elmaci, E., \& Gündoğdu, T. (2016). The effect of concept mapping on students' academic achievement and attitude in science education. Journal of Human Sciences, 13(1), 348-363.

Davies, M. (2011). Concept mapping, mind mapping and argument mapping: what are the differences and do they matter? Higher education, 62(3), 279-301. doi: 10.1007/s10734-010-9387-6.

Dhindsa, H. S., \& Anderson, O. R. (2011). Constructivist-visual mind map teaching approach and the quality of students' cognitive structures. Journal of Science Education and Technology, 20(2), 186200. doi 10.1007/s10956-010-9245-4

Eppler, M. J. (2006). A comparison between concept maps, mind maps, conceptual diagrams, and visual metaphors as complementary tools for knowledge construction and sharing. Information visualization, 5(3), 202-210. doi:10.1057/palgrave.ivs.9500131.

Erinosho, S. Y. (2013). How do students perceive the difficulty of Physics in secondary school? International Journal for Cross-Disciplinary Subjects in Education (IJCDSE), 3(3), 1514.

Ezeudu, F. O. (2013). Influence of concept maps on performance and retention of senior secondary school students in organic chemistry. Journal of Education and Practice, 4(19), 35-43.

Feinstein, A. (2011). Multiple sclerosis and depression. Multiple Sclerosis Journal, 17(11), 12761281 DOI: $10.1177 / 1352458511417835$ msj.sagepub.com

Gagić, Z. Z., Skuban, S. J., Radulović, B. N., Stojanović, M. M., \& Gajić, O. (2019). The implementation of mind maps in teaching physics: educational efficiency and students' involvement. Journal of Baltic Science Education, 18(1), 117-131

Harry, I. H. (2011). Attitude of students towards science and science education in Nigeria (A case study of selected secondary schools in Rivers State). Continental J. of Educational Research, 4(2), 3351

Jibrin, A. G., Abdullahi, Y., Zayum, S. D., \& Abdullahi, Y. A. (2012). Effects of mind mapping instructional strategy on the academic achievement of senior secondary school biology students in ecology. Journal of Science, Technology \& Education, 1(2), 1-5 
John T. A., \& Benjamin I. I. (2015). Gender differences in Mathematics achievement and retention scores: A case of problem-based learning method. International Journal of Research in Education and Science, $1(1), 948-955$

Kiboss, J. (2011) Influence of E-Learning Environment Program on Pupils' Instructional Approaches in Physics Measurement Lessons in Kenyan Secondary Schools. Creative Education, 2, 244-251. doi: 10.4236/ce.2011.23033.

King'aru, J. M. (2014). Factors contributing to poor performance of science subjects: a case of secondary schools in kawe division, Kinondoni municipality. M.Ed. Dissertation, Open University of Tanzania

Mirko, G., Dusanka, Z. O., \& Mirjana, S. (2012). Effective teaching of physics and scientific method. TEM Journal, 1(2), $85-89$

Obunwo, J. (2014). Concept mapping : An instructional strategy for retention of organic chemistry concepts. International Journal of Scientific Research and Innovative Technology, 1(3), 50-57.

Ogunleye, A. O. (2009). Teachers' and Students' Perceptions of Students' Problem-Solving Difficulties in Physics: Implications for Remediation, Journal of College Teaching \& Learning, 6, 785-796

Ogunleye, B. O., \& Babajide, V. F. T. (2011). Generative instructional strategy enhances senior secondary school students' achievement in physics. European Journal of Educational Studies, 3(3), 453-63

Okeke, O. J. (2011). Effect of mind mapping teaching strategy on students' achievement, Interest and retention in senior secondary school Chemistry (Unpublished Ph. D thesis), University of Nigeria, Nsukka, Nigeria.

Okeke, E. A. C. (2012). Clarification and analysis of gender concepts. Focus on research, reproductive health education and gender sensitive classrooms. School Teachers Association of Nigeria, Gender and STM Education Series, Ibadan, Nigeria, 2, 5-8.

Oluwatosin, O. B., \& Bello, T .O (2014). Achievement in Physics using mastery learning and mind mapping approaches: Implication on gender and attitude. International Journal of Humanities Social Sciences and Education, 1(12), 154-161.

Oluwatosin, O. B., \& Bello, T .O. (2015). Comparative effect of mastery learning \& mind mapping approaches in improving secondary school students' learning outcomes in Physics. Science Journal of Education, 3(4), 78-84.

Oladejo, M. A., Olosunde, G. R., Ojebisi, A. O., \& Isola, O. M. (2011). Instructional materials and students' academic achievement in Physics: some policy implications. European Journal of Humanities and Social Sciences, 2(1), 220-225.

Onyishi, E. U. (2009). Effect of mind maps on students' interest and achievement in measures of central tendency in Mathematics (Unpublished Ph.D. thesis), University of Nigeria, Nsukka, Nigeria.

Parikh, N. D. (2015). Mind map and concept map as complementary tools for teaching. The International Journal of Indian Psychology, 2(4), 147-158.

Spencer, J. R., Anderson, K. M, \& Ellis, K. K. (2013). Radiant thinking and the use of the mind map in nurse practitioner education. The Journal of Nursing Education, 52(5), 291-293, http://dx.doi.org/10.3928/01484834-20130328-03 
Tebabal, A., \& Kahssay, G. (2011). The effects of student-centre approach in improving students' graphical interpretation skills and conceptual understanding of kinematical motion. Latin-American Journal of Physics Education, 5(2), 374 - 381

Udousoro, U. J. (2011). The effect of gender and mathematics ability on academic performance of students in Chemistry. African Research Review, International Multidisciplinary Journal, Ethiopia, 5(4), 201-213.

Yoon, H., \& Kang, S. (2015). The effect of integrated mind map activities on the creative thinking skills of 2nd year students in junior high school. Journal of the Korean Chemical Society, 59(2), 164178 . 